\title{
Agrometeorological characteristics of spring oat varieties created in the conditions of the Northern Trans-Urals
}

\author{
M.N. Fomina* \\ Federal State Institutions Federal Research Centre Tyumen Scientific Centre of Siberian Branch of \\ the Russian Academy of Sciences (Tyumen Scientific Centre SB RAS), Tyumen, Russian
}

\begin{abstract}
An agrometeorollological assessment of five oat varieties (Megion, Talisman, Otrada, Foma, Tobolyak) of the breeding of the Northern Trans-Urals Research Institute of Agriculture - branch of the TyumSC SB RAS is given. The effect of the average daily air temperature and precipitation on the growth and development of plants has been established. The sensitivity of varieties to temperature is estimated. It was found that the optimal average daily air temperature during the sprout - ear emergence period was $16.4 \ldots 16.8^{\circ} \mathrm{C}$, during the ear emergence - waxy ripeness period $-17.5 \ldots 19.4^{\circ} \mathrm{C}$. The sums of effective temperatures over $10^{\circ} \mathrm{C}$ necessary for optimal growth and development of oat varieties are calculated. Varieties Megion, Talisman, Foma and Tobolyak in the period of sprout - ear emergence required a greater amount of effective temperatures $\left(705.2 \ldots 747.0^{\circ} \mathrm{C}\right)$ than in the period of ear emergence - wax ripeness $\left(611.2 \ldots 640.2^{\circ} \mathrm{C}\right)$. In the Otrada variety, the need for heat was slightly higher in the second interphase period $\left(717.5^{\circ} \mathrm{C}\right)$ compared to the first $\left(705.6^{\circ} \mathrm{C}\right)$. The optimal amount of precipitation required for the formation of a high yield $(189.4 \ldots 243.6 \mathrm{~mm})$ is calculated. To realize the genetic potential of the Talisman and Otrada varieties, most of the precipitation is necessary during the sprout - ear emergence period, and the Megion, Foma and Tobolyak varieties - during the period of ear emergence - waxy ripeness.
\end{abstract}

\section{Introduction}

The main factors of crop production development are climatic conditions [1-4]. The influence of natural and climatic factors on the formation of yield and the quality of the products obtained from agricultural crops has been repeatedly emphasized by many researchers [5-12]. Nevertheless, it is equally important to know not only the requirements for heat, moisture, and the length of the day for the crop as a whole, but also for individual varieties of this crop. Knowing the requirements of the variety for agrometeorological conditions and climatic resources of various territories, it is possible to determine the zones of its cultivation [13]

\footnotetext{
* Corresponding author: maria_f72@mail.ru
} 
To increase the yield of agricultural crops, new highly productive varieties are needed, adapted to a specific type of meteorological conditions not only in space, but also in time. When creating and selecting a variety for a specific soil and climatic zone, it is necessary to know the agrometeorological characteristics of the territory and the variety. For the variety, the main factors of growth and development are optimal air temperatures and precipitation. The maximum and minimum values of heat and moisture, as the variety approaches them, inhibits growth and development, lead to a decrease in productivity and quality of the products obtained [14-17].

The agrometeorological characteristic makes it possible to establish optimal, maximum, and minimum values of heat and moisture for the variety, which can become the basis for allocating the area of its cultivation.

The purpose of the research is to give an agrometeorological assessment of spring oat varieties created in Russia on the basis of long-term field observations in the Northern Trans-Urals.

\section{Materials and methods}

The work was carried out in 2012-2020 at the experimental field of the Northern TransUrals Research Institute - branch of the Tyumen Research Center SB RAS (Tyumen Region, Tyumen district). The objects of research were varieties of spring oat selected by the Northern Trans-Urals Research Institute, registered in the Ural, West Siberian, East Siberian and Far Eastern regions: Megion, Talisman, Otrada, Foma, Tobolyak. All the presented varieties were obtained by hybridization with subsequent selection.

Field observations, assessments and records were carried out in accordance with the methodology of the State Commission for Testing Agricultural Crops [18]. The study was carried out at the final stage of the breeding process (competitive variety testing), the registered area of the plot is $20 \mathrm{~m}^{2}$ in 4-fold repetition. The soil of the experimental site is gray forest, podzolized, heavy loamy. The hydrolytic acidity $(\mathrm{pH})$ of the salt extract is 5.46.0. The capacity of the arable horizon is $18-30 \mathrm{~cm}$, the humus content in the soil (for absolutely dry matter) is $2.65-4.47 \%$. Content of $\mathrm{NO}_{3}-2.00-2.30 ; \mathrm{P}_{2} \mathrm{O}_{5}-5.9-6.2 ; \mathrm{K}_{2} \mathrm{O}-$ $8.0-25.7 \mathrm{mg} / 100 \mathrm{~g}$ of soil. The main and pre-sowing tillage was carried out in accordance with the zonal system of agriculture of the Tyumen region [19].

The agrometeorological characteristics of the varieties were compiled according to the methodological guidelines [20].

The sensitivity of the varieties to temperature conditions was evaluated by the variability index (x) [21]. Statistical data processing was carried out using the field experiment methodology [22].

The weather conditions in the years of the research (2012-2020) differed in the provision of heat and moisture. The spring-summer period of 2012 was dry and hot. The sum of effective temperatures by the end of August exceeded the norm by $438^{\circ} \mathrm{C}$. The HTC (hydrothermal coefficient) for the period May-August was 0.44 . The growing season of 2013 was characterized by warm and humid weather $(\mathrm{HTC}=1.90)$. The sum of effective temperatures during the growing season (May-August) was higher than normal by $116^{\circ} \mathrm{C}$. The spring-summer period of 2014 was wet and cool $(\mathrm{HTC}=1.89)$. A significant lack of heat and excess moisture was noted in July, when the average daily air temperature was lower than the long-term average by $4.0^{\circ} \mathrm{C}$, the amount of precipitation for this month exceeded the norm by $44.9 \%$. By the end of the month, the shortfall in the amount of effective temperatures was $42^{\circ} \mathrm{C}$. The missing heat was compensated due to the high average daily temperatures in August. The sum of the effective temperatures by the end of August was $1890^{\circ} \mathrm{C}(102 \%$ of the norm). The growing season of 2015 was humid with a large fluctuation of average daily temperatures $(\mathrm{HTC}=1.81)$, the average daily 
temperatures in May and June exceeded the norm by 25-26\%, in July - August their values were $12 \%$ lower than the long-term average. The meteorological conditions of 2016 were characterized by instability during the entire growing season. May was warm and dry, June was within the normal range, July was hot, with periodic precipitation. August was characterized by dry and hot weather $(\mathrm{HTC}=0.69)$. The weather conditions of the growing season in 2017 were characterized by excessive moisture and lack of heat in June and July $(\mathrm{HTC}=1.48)$. August was warm and dry $(\mathrm{HTC}=0.86)$. The growing season of 2018 was wet (HTC for May - August was 1.68) with a shortage of heat (the sum of active temperatures of $1825^{\circ} \mathrm{C}$ at a norm of $1844^{\circ} \mathrm{C}$ ). May was especially wet and cold (HTC $=3.24)$ and partly June $(\mathrm{HTC}=1.36)$. July was dry and hot $(\mathrm{HTC}=0.80)$. August was humid with an average daily temperature within the normal range $\left(15.5^{\circ} \mathrm{C}\right)$. The contrast was distinguished in the climatic conditions of 2019. May was warm with a sufficient amount of precipitation $(\mathrm{HTC}=1.04)$. June and the first decade of July were characterized by a lack of heat and excessive moisture $(\mathrm{HTC}=1.74)$. The second half of July and August were quite warm and humid. The sum of active temperatures for the growing season (MayAugust) was $1906^{\circ} \mathrm{C}$ (above the norm by $62^{\circ} \mathrm{C}$ ), $\mathrm{HTC}=1.57$ (norm 1.31 ). The growing season of 2020 was dry and warm. The sum of active temperatures from May to August was $2133^{\circ} \mathrm{C}, \mathrm{HTC}=0.89$.

\section{Results and their discussion}

The natural and climatic conditions of the Northern Trans-Urals, as well as many regions of the Urals and Siberia, are characterized by a short frost-free period and uneven precipitation during the growing season. The reaction of varieties to changes in temperature conditions and the amount of precipitation was ambiguous.

During the sowing - sprout period, varietal differences were not manifested, so a comparative assessment was carried out in the periods: sprout - ear emergence and ear emergence - wax ripeness.

The increase in the average daily air temperature in most varieties significantly shortened the duration of interphase periods. A strong negative relation was established between the average daily temperature and the period of sprout - ear emergence $(r=-0.76$ ...- 0.81) and from medium to strong with the period of ear emergence - wax ripeness $(\mathrm{r}=$ $0.67 \ldots-0.83$ ). The exception was the Tobolyak variety, which reacted poorly to an increase in the average daily temperature during the first interphase period of vegetation ( $\mathrm{r}$ $=-0.27$ ). An unambiguous reaction to the change in the average daily air temperature in both interphase periods was observed in the varieties Megion $\left(r_{1}=-0.79 ; r_{2}=-0.79\right)$ and Otrada $\left(\mathrm{r}_{1}=-0.81 ; \mathrm{r}_{2}=-0.82\right)$. The Talisman and Tobolyak varieties reacted more strongly to changes in the heat regime during the period of ear emergence - wax ripeness $(r=-0.83$; $r=-0.72)$. The Foma variety $(r=-0,67)$ reacted less than others to changes in temperature conditions in the second period (ear emergence - wax ripeness) (Table 1).

Table 1. The dependence of the growth and development rates of oat varieties $(\mathrm{Y})$ on the average air temperature during the growing season (x), Tyumen, 2012-2020.

\begin{tabular}{|l|c|c|}
\hline \multicolumn{1}{|c|}{ Period } & $\begin{array}{c}\text { Correlation } \\
\text { coefficient }\left(\mathrm{r} \pm \mathrm{S}_{\mathrm{r}}\right)\end{array}$ & Relation equation \\
\hline Megion & $-0.79 \pm 0.12^{*}$ & $\mathrm{Y}=-1.86 \mathrm{x}+72.01$ \\
\hline Sprouts - ear emergence & $-0.79 \pm 0.12^{*}$ & $\mathrm{Y}=-2.10 \mathrm{x}+71.64$ \\
\hline Ear emergence - wax ripeness & $-0.76 \pm 0.14^{*}$ & $\mathrm{Y}=-1.92 \mathrm{x}+74.73$ \\
\hline Talisman & $-0.83 \pm 0.10^{*}$ & $\mathrm{Y}=-0.21 \mathrm{x}+36.37$ \\
\hline Sprouts - ear emergence & \\
\hline Ear emergence - wax ripeness & \multicolumn{3}{|l|}{} \\
\hline Otrada
\end{tabular}




\begin{tabular}{|l|c|c|}
\hline Sprouts - ear emergence & $-0.81 \pm 0.11^{*}$ & $\mathrm{Y}=-1.87 \mathrm{x}+73.37$ \\
\hline Ear emergence - wax ripeness & $-0.82 \pm 0.11^{*}$ & $\mathrm{Y}=-1.97 \mathrm{x}+70.78$ \\
\hline Foma & $-0.76 \pm 0.14^{*}$ & $\mathrm{Y}=-1.71 \mathrm{x}+71.46$ \\
\hline Sprouts - ear emergence & $-0.67 \pm 0.18^{*}$ & $\mathrm{Y}=-1.77 \mathrm{x}+63.83$ \\
\hline Ear emergence - wax ripeness & $-0.27 \pm 0.33$ & $\mathrm{Y}=-0.65 \mathrm{x}+55.28$ \\
\hline Tobolyak & $-0.72 \pm 0.17^{*}$ & $\mathrm{Y}=-1.29 \mathrm{x}+56.94$ \\
\hline Sprouts - ear emergence
\end{tabular}

* significant at the level of $5 \%$

The calculated equations of the relation between the growth and development rates of oat varieties with the air temperature allowed to determine the optimal and minimum duration of interphase periods for each variety. The average duration of interphase periods in years with high yield of varieties was used as the optimal one. It was 42-45 days (sprouts - ear emergence) and 32-41 days (ear emergence - wax ripeness). In years with low yields, there can be both long interphase periods, depending on low temperatures, and short ones, determined by an increased amount of heat. In our experiments, there were no years with low yield and long interphase periods, only short interphase periods were observed, which averaged from 32 to 42 days (sprouts - ear emergence) and from 22 to 30 days (ear emergence - wax ripeness) (Table 2).

Table 2. The most probable duration of interphase periods (days) in the years of high (numerator) and low (denominator) yields.

\begin{tabular}{|c|c|c|c|}
\hline \multirow{2}{*}{ Variety } & \multicolumn{3}{|c|}{ Periods } \\
\cline { 2 - 4 } & $\begin{array}{c}\text { Sprouts - ear } \\
\text { emergence }\end{array}$ & $\begin{array}{c}\text { Ear emergence - wax } \\
\text { ripeness }\end{array}$ & $\begin{array}{c}\text { Sprouts - wax } \\
\text { ripeness }\end{array}$ \\
\hline Megion & $\frac{43}{32}$ & $\frac{33}{22}$ & $\frac{76}{54}$ \\
\hline Talisman & $\frac{43}{34}$ & $\frac{32}{24}$ & $\underline{75}$ \\
\hline Otrada & $\underline{42}$ & $\frac{41}{25}$ & $\underline{53}$ \\
\hline Foma & $\frac{44}{34}$ & $\underline{32}$ & $\frac{76}{24}$ \\
\hline Tobolyak & $\underline{45}$ & $\underline{33}$ & $\frac{78}{30}$ \\
\hline
\end{tabular}

The sensitivity of the varieties to temperature conditions was evaluated by the variability index (x). The Tobolyak variety was characterized by weak sensitivity, which had the lowest variability indicators in both interphase periods $(1.07 ; 1.10)$. The Megion variety reacted more strongly to the temperature change than others $(\mathrm{x}=1.34 \ldots 1.50)$. The varieties Talisman, Otrada and Foma reacted almost unambiguously to the temperature background in the first interphase period $(\mathrm{x}=1.26 \ldots 1.29)$. The Otrada variety $(\mathrm{x}=1.64)$ was more sensitive to temperature conditions during the period of ear emergence - wax ripeness (Table 3 ).

Table 3. Sensitivity of oat varieties to temperature conditions in interphase periods.

\begin{tabular}{|l|c|c|}
\hline \multirow{2}{*}{ Variety } & \multicolumn{2}{|c|}{ Variability indes (x) } \\
\cline { 2 - 3 } & $\begin{array}{c}\text { Sprouts - ear } \\
\text { emergence }\end{array}$ & $\begin{array}{c}\text { Ear emergence - wax } \\
\text { ripeness }\end{array}$ \\
\hline Megion & 1.34 & 1.50 \\
\hline Talisman & 1.26 & 1.33 \\
\hline Otrada & 1.27 & 1.64 \\
\hline Foma & 1.29 & 1.33 \\
\hline
\end{tabular}




\begin{tabular}{|l|l|l|}
\hline Tobolyak & 1.07 & 1.10 \\
\hline
\end{tabular}

$* \mathrm{x}$ - the ratio of the period duration at $\min \mathrm{t}^{\circ} \mathrm{C}$ to the period duration at $\max \mathrm{t}^{\circ} \mathrm{C}$.

The conducted studies made it possible to determine the optimal and maximum development temperatures for each variety in separate interphase periods. During the sprouts - ear emergence period, there were no significant differences in the need for heat in all varieties. The optimum for this period was $16.4 \ldots 16.8^{\circ} \mathrm{C}$. The reaction of varieties to high air temperatures was ambiguous. The maximum temperature of growth and development in the first interphase period in the Megion, Otrada and Foma varieties was $20.0 \ldots 21.4^{\circ} \mathrm{C}$. The Talisman and Tobolyak varieties required lower temperatures $(20.6$ and $19.1^{\circ} \mathrm{C}$, respectively). The optimal temperatures of the second growing season (ear emergence - wax ripeness) were $17.5 \ldots 19.4^{\circ} \mathrm{C}$. Higher average daily temperatures during this period were required by the varieties Megion, Talisman and Foma. The Otrada and Tobolyak varieties grew better and developed at a lower temperature $\left(17.5\right.$ and $18.6^{\circ} \mathrm{C}$, respectively) (Table 4).

Table 4. Optimal (numerator) and maximum (denominator) development temperatures and the range between them in oat varieties in separate interphase periods, Tyumen, 2012-2020.

\begin{tabular}{|c|c|c|c|c|}
\hline \multirow[b]{2}{*}{ Variety } & \multicolumn{2}{|c|}{ Sprouts - ear emergence } & \multicolumn{2}{|c|}{ Ear emergence - wax ripeness } \\
\hline & $\frac{\text { opt } t^{\circ} \mathrm{C}}{\max t^{\circ} \mathrm{C}}$ & range, $\mathrm{t}^{\circ} \mathrm{C}$ & $\frac{\text { opt t } t^{\circ} \mathrm{C}}{\max t^{\circ} \mathrm{C}}$ & range, $\mathrm{t}^{\circ} \mathrm{C}$ \\
\hline Megion & $\frac{16.4}{21.0}$ & 4.6 & $\frac{19.4}{21.7}$ & 2.3 \\
\hline Talisman & $\frac{16.4}{20.6}$ & 4.2 & $\frac{19.4}{21.1}$ & 1.7 \\
\hline Otrada & $\frac{16.8}{21.0}$ & 4.2 & $\frac{17.5}{21.4}$ & 3.9 \\
\hline Foma & $\frac{16.5}{21.4}$ & 4.9 & $\frac{19.1}{21.2}$ & 2.1 \\
\hline Tobolyak & $\frac{16.6}{19.1}$ & 2.5 & $\frac{18.6}{20.5}$ & 1.9 \\
\hline
\end{tabular}

The range between the optimal and maximum temperature of growth and development can serve as an indirect indicator of the variety plasticity to the cultivation conditions. Among the studied varieties, the Otrada variety was more plastic with a temperature range in the period of sprouts - ear emergence $-4.2^{\circ} \mathrm{C}$, in the period of ear emergence - wax ripeness $-3.9^{\circ} \mathrm{C}$. The Tobolyak variety was distinguished by a narrow temperature range in both interphase periods (the first period $-2.5^{\circ} \mathrm{C}$; the second $-1.9^{\circ} \mathrm{C}$ ), which indicates low plasticity of this variety.

Considering the temperatures necessary for optimal plant growth and development at different time intervals, the optimal sums of effective temperatures were determined for each variety. During the growing season, they ranged from 1337.2 to $1423.1^{\circ} \mathrm{C}$. The analysis of the temperature regime of the studied oat varieties showed that each of them in the process of growth and development needed not only a certain amount of effective temperatures, but also had features for the need for heat in a certain period of time. Most of the presented varieties are more heat needed in the period from sprouts - ear energence $\left(705.2 \ldots 747.0^{\circ} \mathrm{C}\right)$ than in the period of ear energence - wax ripeness $\left(611.2 \ldots 640.2^{\circ} \mathrm{C}\right)$. The exception was the Otrada variety, which heating demand was slightly higher in the second interphase period (ear energence - wax ripeness) (Fig. 1). 


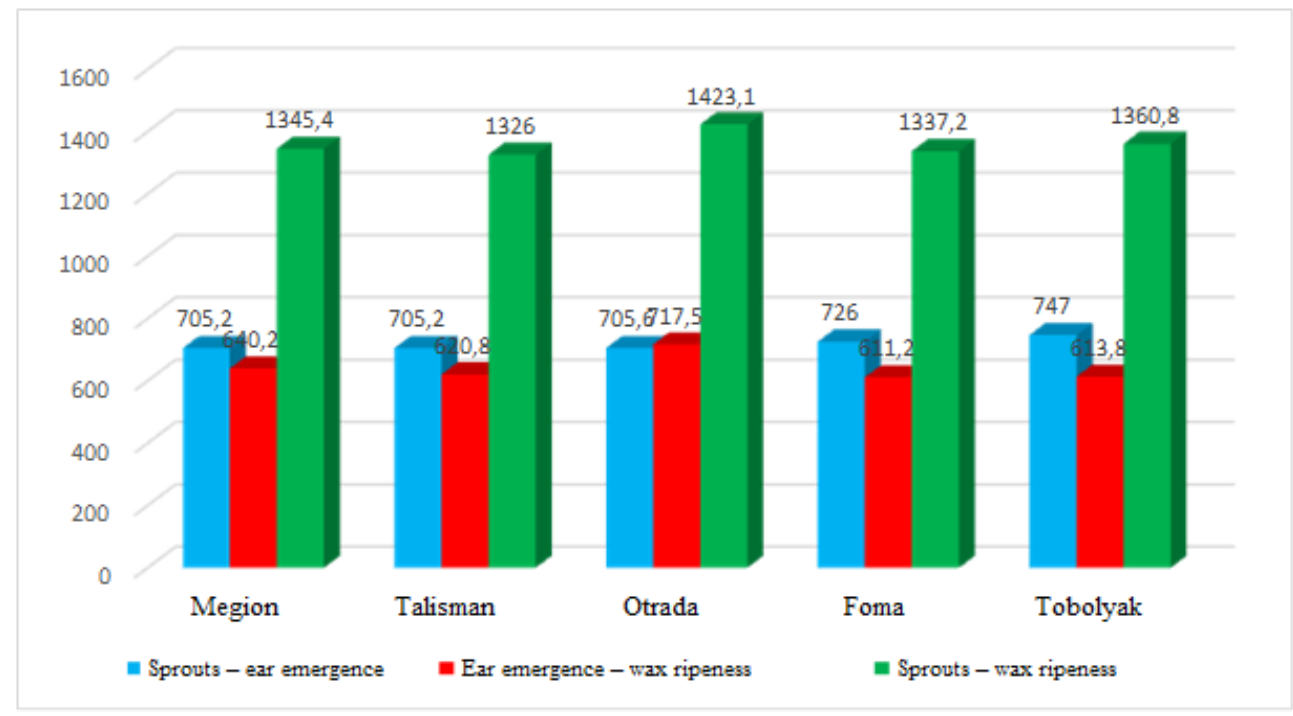

Fig. 1. The sum of effective temperatures over $10^{\circ} \mathrm{C}$, necessary for optimal growth and development of oat varieties in the conditions of the Northern Trans-Urals.

An equally important factor necessary for the normal growth and development of plants is the presence of moisture. The dependence of the growth and development rates of oat varieties on the amount of precipitation, established by us, indicates that a high need for precipitation during the sprouts - ear emergence period was seen in the Talisman, Otrada and Foma varieties $(r=0.69 \ldots 0.77)$. A negative reaction to precipitation in the first half of the growing season was noted in the Megion variety $(r=-0.42)$ and almost no connection was observed in the Tobolyak variety $(\mathrm{r}=0.22)$. The precipitation of the second half of the growing season was used more intensively by the Megion variety $(r=0.47)$ (Table 5$)$.

Table 5. The dependence of the growth and development rates of oat varieties $(\mathrm{Y})$ on the amount of precipitation that fell during the growing season (x), Tyumen, 2012-2019.

\begin{tabular}{|c|c|c|}
\hline Period & $\begin{array}{c}\text { Correlation coefficient } \\
\left(\mathrm{r} \pm \mathrm{S}_{\mathrm{r}}\right)\end{array}$ & Relation equation \\
\hline \multicolumn{3}{|l|}{ Megion } \\
\hline Sprouts - ear emergence & $-0.42 \pm 0.29 *$ & $\mathrm{Y}=0.07 \mathrm{x}+31.82$ \\
\hline Ear emergence - wax ripeness & $0.47 \pm 0.28 *$ & $\mathrm{Y}=0.09 \mathrm{x}+26.23$ \\
\hline \multicolumn{3}{|l|}{ Talisman } \\
\hline Sprouts - ear emergence & $0.69 \pm 0.18^{*}$ & $Y=0.05 x+34.98$ \\
\hline Ear emergence - wax ripeness & $0.33 \pm 0.31$ & $\mathrm{Y}=0.05 \mathrm{x}+29.48$ \\
\hline \multicolumn{3}{|l|}{ Otrada } \\
\hline Sprouts - ear emergence & $0.77 \pm 0.14 *$ & $\mathrm{Y}=0.07 \mathrm{x}+32.83$ \\
\hline Ear emergence - wax ripeness & $0.23 \pm 0.33$ & $\mathrm{Y}=0.04 \mathrm{x}+30.56$ \\
\hline \multicolumn{3}{|l|}{ Foma } \\
\hline Sprouts - ear emergence & $0.77 \pm 0.14 *$ & $Y=0.07 x+33.62$ \\
\hline Ear emergence - wax ripeness & $0.29 \pm 0.32$ & $\mathrm{Y}=0.05 \mathrm{x}+28.99$ \\
\hline \multicolumn{3}{|l|}{ Tobolyak } \\
\hline Sprouts - ear emergence & $0.22 \pm 0.36$ & $Y=0.015 x+41.80$ \\
\hline Ear emergence - wax ripeness & $-0.24 \pm 0.36$ & $Y=-0.03 x+35.85$ \\
\hline
\end{tabular}

* significant at the level of $5 \%$ 
The optimal amount of precipitation calculated by us, necessary for the formation of a high yield, was from $189.4 \mathrm{~mm}$ (Talisman), depending on the variety up to $243.6 \mathrm{~mm}$ (Tobolsk). At the same time, to realize their genetic potential, the Talisman and Otrada varieties needed most of the precipitation during the sprouts - ear emergence period, and the Megion, Foma and Tobolyak varieties - during the ear emergence - wax ripeness (Table $6)$.

Table 6. The optimal amount of precipitation $(\mathrm{mm})$ required for the realization of the genetic potential of oat varieties in the conditions of the Northern Trans-Urals, 2012-2019.

\begin{tabular}{|l|c|c|c|}
\hline \multirow{2}{*}{ Variety } & \multicolumn{3}{|c|}{ Periods } \\
\cline { 2 - 4 } & $\begin{array}{c}\text { Sprouts - ear } \\
\text { emergence }\end{array}$ & $\begin{array}{c}\text { Ear emergence }- \text { wax } \\
\text { ripeness }\end{array}$ & $\begin{array}{c}\text { Sprouts }- \text { wax } \\
\text { ripeness }\end{array}$ \\
\hline Megion & 102.8 & 130.8 & 233.6 \\
\hline Talisman & 97.0 & 92.4 & 189.4 \\
\hline Otrada & 150.6 & 53.1 & 203.7 \\
\hline Foma & 102.8 & 130.8 & 233.8 \\
\hline Tobolyak & 102.5 & 141.1 & 243.6 \\
\hline
\end{tabular}

\section{Conclusions}

An agrometeorollological assessment of five oat varieties (Megion, Talisman, Otrada, Foma, Tobolyak) of the breeding of the Northern Trans-Urals Research Institute of Agriculture - branch of the TyumSC SB RAS is given. The effect of the average daily air temperatures and precipitations on the growth and development of plants has been established. The optimal and minimum duration of interphase periods is determined for each variety. The sensitivity of varieties to temperature fluctuations is estimated. The optimal average daily air temperature in the interphase periods is established. In the period of sprouts - ear energence, it was $16.4 \ldots 16.8^{\circ} \mathrm{C}$, ear emergence - wax ripeness $17.5 \ldots 19.4^{\circ} \mathrm{C}$. Varieties Megion, Talisman and Foma in the second interphase period (ear emergence - wax ripeness) required higher average daily temperatures $\left(19.1 \ldots 19.4^{\circ} \mathrm{C}\right)$ than Otrada and Tobolyak $\left(17.5 \ldots 18.6^{\circ} \mathrm{C}\right)$. The sums of effective temperatures over $10^{\circ} \mathrm{C}$ necessary for optimal growth and development of oat varieties $\left(1337.2 \ldots 1423.1^{\circ} \mathrm{C}\right)$ are calculated. Varieties Megion, Talisman, Foma and Tobolyak in the period of sprout - ear emergence required a greater amount of effective temperatures $\left(705.2 \ldots 747.0^{\circ} \mathrm{C}\right)$ than in the period of ear emergence - wax ripeness $\left(611.2 \ldots 640.2^{\circ} \mathrm{C}\right)$. In the Otrada variety, the need for heat was slightly higher in the second interphase period $\left(717.5^{\circ} \mathrm{C}\right)$ compared to the first $\left(705.6^{\circ} \mathrm{C}\right)$. The optimal amount of precipitation necessary for the formation of a high yield $(189.4 \ldots 243.6 \mathrm{~mm})$ is calculated, while for the realization of the genetic potential of the Talisman and Otrada varieties, most of the precipitation is necessary during the sprouts - ear emergence period, and the Megion, Foma and Tobolyak varieties - during the ear emergence - wax ripeness.

\section{Acknowledgements}

The work was performed according to the state task No. 121041600036-6

\section{References}

1. A.V. Gordeev, A.D. Kleshchenko, B.A. Chernyakov, O.D. Sirotenko, Bioclimatic potential of Russia: theory and practice, 521 (Moscow, Russia, 2006) 
2. E.A. Grigorieva, A. Matzarakis A., C.R. de Freitas, Clim. Res (42), 143-154 (2010)

3. E. Grigorieva, Atmosphere (11) 404 (2020)

4. F. Cabré, M Nuñez, Reg. Environ. Chang (20), 12 (2020)

5. M.S. Arzumanyan, Bulletin of the Krasnoyarsk SAU, Krasnoyarsk, (6), 35-42 (2014)

6. A.I. Grabovets, M.A. Fomenko, Achievements of science and technology of the agroindustrial complex (12), 16-19 (2015)

7. M.A. Rozova, V.N. Mukhin, Achievements of science and technology of the agroindustrial complex (8), 58-61 (2015)

8. A.V. Sorokina, G.N. Komarova, Siberian bulletin of agricultural science (6), 55-60 (2014)

9. A.V. Zaushintsena, A.A. Startsev, S.V. Svirkova, Modern problems of science and education (5), 331-334 (2016)

10. H. Matsuda, M. Chuba, Sh. Mori, H. Fujii, Japan J. Crop Sc. 83(3), 242-248 (2014)

11. Wang Zhan-biao, Wang Meng, Yin Xiao-gang, et al., J. China Agr.Univ. 20 (5), 16-23 (2015)

12. N.M. Ruzdik, D.Valcheva, L Mihajlov, et al., Bulg. J. agr. Sc. 21(4), 863-871 (2015)

13. N.V. Ionina, L.T. Maltseva, E.A. Filippova, Agrarian Bulletin of the Urals (5), 13-16 (2015)

14. D.C. Doehlert, M.S. McMullen, J. J. Hammond, Crop Sc. 41(4), 1066-1072 (2001)

15. I.V. Kosakovskaya, L.V. Voitenko, R.V. Likhnevsky, A.Yu. Ustinova, Plant physiology and genetics 47(4), 296-303 (2015)

16. F. Fras, D. Boros, Biul.Inst. Hodowli Aklimat. Rosl, Warszawa, (277) 21-32 (2015)

17. S. Knapp, R. Aebi, M. Anders, et al., Recherche Agronomique Suisse, (7-8), 312-319 (2015)

18. Methodology of the State Commission for Testing agricultural crops, 269 (Moscow, 1983)

19.Zonal system of agriculture of the Tyumen region: Recommendations, 444 (Novosibirsk, 1989)

20. Methodological guidelines for the compilation of agrometeorological characteristics of plant varieties (on the example of Cucumis sativus L. cucumber), 23 (Leningrad, 1979)

21. E. V. Yudina, Collection of scientific papers on applied botany, genetics and breeding (84), 103-108 (1984)

22. B.A. Dospekhov, Methodology of field experience (with the basics of statistical processing of research results), 416 (1979) 